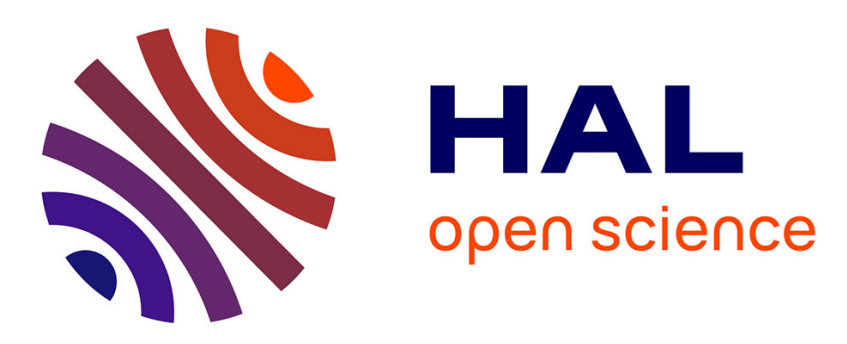

\title{
Building and Maintaining the Common Ground in Web-Based Interaction
}

\author{
Kati Mäkitalo, Päivi Häkkinen, Piritta Salo, Sanna Järvelä
}

\section{To cite this version:}

Kati Mäkitalo, Päivi Häkkinen, Piritta Salo, Sanna Järvelä. Building and Maintaining the Common Ground in Web-Based Interaction. Computer support for collaborative learning: Foundations for a CSCL community (CSCL 2002), 2002, United States. pp.571-572. hal-00197410

HAL Id: hal-00197410 https://telearn.archives-ouvertes.fr/hal-00197410

Submitted on 14 Dec 2007

HAL is a multi-disciplinary open access archive for the deposit and dissemination of scientific research documents, whether they are published or not. The documents may come from teaching and research institutions in France or abroad, or from public or private research centers.
L'archive ouverte pluridisciplinaire HAL, est destinée au dépôt et à la diffusion de documents scientifiques de niveau recherche, publiés ou non, émanant des établissements d'enseignement et de recherche français ou étrangers, des laboratoires publics ou privés. 


\title{
Building and Maintaining the Common Ground in Web- Based Interaction
}

\author{
Kati Mäkitalo, Päivi Häkkinen \\ University of Jyväskylä, Finland \\ kati.makitalo@ktl.jyu.fi \\ Piritta Salo, Sanna Järvelä \\ University of Oulu, Finland
}

\begin{abstract}
In this paper, the main purpose is to explore how participants establish and maintain the common ground in the computer-based conferences. Previous studies assume that before the participants can reach the deeper level interaction and learning, they have to gain an adequate level of common ground (Dillenbourg, 1999; Baker et al., 1999; Veerman, 2000). Subjects were 68 pre-service teachers and 7 mentors from three universities who participated in the web-based conferencing course for eight weeks. The results assume that in deeper level discussions it is essential that participants, especially fellow students did give not only the evidence about their own understanding by using written feedback, but also give the support to their co-students and show their attitudinal reaction in their replies.
\end{abstract}

\section{Keywords}

Common ground, feedback, electronic discussion, grounding, web-based interaction

\section{INTRODUCTION}

An adequate level of mutual understanding is a prerequisite in collaborative learning activities. In order to construct the common ground, individuals share mutual understanding, knowledge, beliefs, assumptions and pre-suppositions. The common ground can be constructed and maintained during the interactive process called grounding, which requires a joint effort by participants who meet each other at the first time in computer-mediated communication environment. (Baker et al., 1999) At the beginning of interaction, mentioning of facts and proposals in the presence of another, processes of diagnosis and feedback are essential for building the common ground (Baker et al., 1999; Brennan, 1998). There are four communicative factors, which may arise problems in maintaining common ground: contact, perception, understanding and attitudinal reaction (Allwood et al., 1991). The purpose of this study is to increase knowledge about web-based interaction and learning by exploring the mechanisms of augmenting and maintaining the common ground.

\section{METHODS}

This study is a part of the Finnish research project SHAPE (Sharing and Making Perspectives in Virtual Interaction: Järvelä \& Häkkinen, 2001; Saarenkunnas et al., 2000). The subjects of the study were pre-service teachers in the USA, University of Indiana $(\mathrm{N}=35)$, and Finland, Universities of Jyväskylä $(\mathrm{N}=12)$ and Oulu $(\mathrm{N}=21)$. The students' learning task was to construct and maintain their case discussion and to summarise the discussion in the middle of the computer-supported learning course period and also at the end of it by using an asynchronous web-based learning environment called ProTo.

\section{DATA COLLECTION AND ANALYSIS}

The data of this study contained 36 written case discussions. In each discussion there were from 4 to 26 messages, in total 449 messages. Multi-phase analysis procedure was used in the following way:

A level of discussions (Progressive and Deeper level discussions; Järvelä \& Häkkinen, 2001)

Types of postings (Comment, Suggestion, Experience, New Point/Question, Theory)

Cross-references to the other postings

A type of feedback

\section{RESULTS}

Results show that 18 case discussions out of 36 were categorized to the progressive level and the other half to the deeper level discussions. The progressive level discussions involved plenty of comments, experience-based postings and postings with new points or questions and some cross-references. Deeper level discussions involved a lot of theorybased postings as well as new points or questions and plenty of cross-references. Results show that $49 \%$ of the total amount of postings included the written feedback of some kind. The number and type of students' feedback are reported in Table 1. The difference of the feedback used by students in different levels of discussions is statistically significant 
$(\mathrm{p}=0.094)$. Especially, standardized residuals are statistically significant in the use of supporting feedback by students. There were no differences found in the feedback use of mentors in different levels of discussions or between students and mentors.

Table 1. The feedback use of students in progressive and deeper level discussions

\begin{tabular}{|c|c|c|c|}
\hline Types of Feedback & $\begin{array}{c}\text { Progressive } \\
\text { Level } \\
\text { Discussions }\end{array}$ & $\begin{array}{c}\text { Deeper } \\
\text { Level } \\
\text { Discussions }\end{array}$ & Total \\
\hline \multirow[t]{2}{*}{ 1. Agree/disagree feedback } & 39 & 29 & 68 \\
\hline & $45,9 \%$ & $30,9 \%$ & $38,0 \%$ \\
\hline \multirow[t]{2}{*}{ 2. Personal feedback } & 17 & 16 & 33 \\
\hline & $20,0 \%$ & $17,0 \%$ & $18,4 \%$ \\
\hline \multirow[t]{2}{*}{ 3. Notifying feedback } & 13 & 21 & 34 \\
\hline & $15,3 \%$ & $22,3 \%$ & $19,0 \%$ \\
\hline \multirow[t]{2}{*}{ 4. Supporting feedback*) } & 4 & 15 & 19 \\
\hline & $4,7 \%$ & $16,0 \%$ & $10,6 \%$ \\
\hline \multirow[t]{2}{*}{ 5. Comparative feedback } & 7 & 7 & 14 \\
\hline & $8,2 \%$ & $7,4 \%$ & $7,8 \%$ \\
\hline \multirow[t]{2}{*}{ 6. Explaining feedback } & 5 & 6 & 11 \\
\hline & $5,9 \%$ & $6,4 \%$ & $6,1 \%$ \\
\hline \multirow[t]{2}{*}{ Total } & 85 & 94 & 179 \\
\hline & $100,0 \%$ & $100,0 \%$ & $100,0 \%$ \\
\hline
\end{tabular}

Person Chi-Square Value $=9.414, \mathrm{df}=5, \mathrm{p}=0.094<0.1$ *)Standardized residuals are statistically significant

\section{CONCLUSION}

These results imply that students provided valuable peer feedback, particularly task- and social oriented supporting feedback, which might lead into the constructive discussion (See also; Hara et al., 2000). Further analysis of maintaining mechanisms of web-based discussion will be demonstrated in the presentation.

\section{REFERENCES}

Allwood, J., Nivre, J. \& Ahlsén, E. 1991. On the Semantics and Pragmatics of Linguistic Feedback (Gothenburg Papers in Theoretical Linguistics No. 64). Sweden: University of Gothenburg, Department of Linguistics.

Baker, M., Hansen, T., Joiner, R. \& Traum, D. (1999) The role of grounding in collaborative learning tasks. In P. Dillenbourg (Ed.) Collaborative learning. Cognitive and computational approaches. Advances in Learning and Instruction Series. Amsterdam: Pergamon, 31-63.

Brennan, S. E. (1998) The grounding problem in conversations with and through computers. In S. R. Fussell \& R. J. Kreuz (Eds.) Social and cognitive approaches to interpersonal communication. Mahwal, NJ: Erlbaum, 201-225.

Dillenbourg, P. (1999) Introduction: What do you mean by "collaborative learning"? In P. Dillenbourg (Ed.) Collaborative learning. Cognitive and computational approaches. Advances in Learning and Instruction Series. Amsterdam: Pergamon, 1-19.

Hara, N., Bonk, C. J. \& Angeli, C. 2000. Content analysis of online discussion in an applied educational psychology course. Instructional Science 28, 115-152.

Järvelä, S. \& Häkkinen, P. (2001, in press) The levels of web-based discussions - using perspective-taking theory as an analysis tool. In H. Van Oostendorp (Ed.) Cognition in a digital world. Lawrence Erlbaum.

Saarenkunnas, M., Järvelä, S., Häkkinen, P., Kuure, L., Taalas, P. \& Kunelius, E. (2000) NINTER - Networked Interaction: Theory-based cases in teaching and learning. Learning Environments Research 3, 35-50. 